\title{
Léon Bloy, Lettres à Paul Jury
}

\section{Ida Merello}

\section{(2) OpenEdition}

\section{Journals}

\section{Edizione digitale}

URL: http://journals.openedition.org/studifrancesi/6395

DOI: 10.4000/studifrancesi.6395

ISSN: 2427-5856

\section{Editore}

Rosenberg \& Sellier

\section{Edizione cartacea}

Data di pubblicazione: 1 novembre 2010

Paginazione: 581

ISSN: 0039-2944

\section{Notizia bibliografica digitale}

Ida Merello, «Léon Bloy, Lettres à Paul Jury», Studi Francesi [Online], 162 (LIV | III) | 2010, online dal 30 novembre 2015, consultato il 13 janvier 2021. URL: http://journals.openedition.org/studifrancesi/6395 ; DOI: https://doi.org/10.4000/studifrancesi.6395

Questo documento è stato generato automaticamente il 13 janvier 2021.

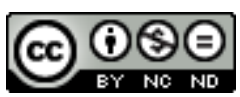

Studi Francesi è distribuita con Licenza Creative Commons Attribuzione - Non commerciale - Non opere derivate 4.0 Internazionale. 


\title{
Léon Bloy, Lettres à Paul Jury
}

\author{
Ida Merello
}

\section{NOTIZIA}

LÉON BLOY, Lettres à Paul Jury, texte édité et présenté par Michel BRIX, Tusson, Du Lérot, pp. 334.

1 Il volume raccoglie lo scambio epistolare del periodo 1894-1905 tra Bloy e l'anomalo personaggio di Paul Jury, attratto prima dai buddisti, poi da un mistico esaltato divenuto suo cognato, finalmente ordinato padre gesuita per liberarsi poi della tonaca $\mathrm{e}$ passare il resto della propria vita a combattere qualsiasi forma di religione, in nome della nuova fede nella psicanalisi freudiana. Le lettere sono molto significative per la comprensione del pensiero di Bloy, facendo luce sul retroterra di opere come Quatre ans de captivité à Cochons-sur-Marne, l'Exégèse des lieux communs e Les dernières colonnes de l'église. Michel Brix fa precedere l'opera da un'ampia introduzione che entra nelle pieghe dell'amicizia tra i due uomini, facendo risaltare il carattere di Bloy, «mendiant ingrat». 